\title{
Ethical Attributes Precipitates Organization Success in Private Universities in Kenya
}

\author{
Bonn Odera Jonyo, DBA \\ Caren Ouma, PhD \\ Zachary Mosoti, PhD
}

United States International University Africa, Kenya

Doi: 10.19044/elp.v7no2a2 ～URL:http://dx.doi.org/10.19044/elp.v7no2a2

\begin{abstract}
The global economy, more than any other factor, has created the need by the top management team to effectively exercise leadership in organizations to bring success. This study examined the contribution of ethical factors in organization management success in private universities in Kenya with a specific research question of how does ethical values affect organizational success in private universities in Kenya? The study was underpinned by the strategic leadership theory. It was a correlational study which adopted a positivist philosophy. The study population comprised of all the 17 private universities in Kenya accredited by Commission of University Education and the unit of analysis was the board of directors, vice chancellors, heads of departments which was one hundred and thirty-six (136). The study found that, ethical values contributed a significant percentage in organizational success, $\mathrm{R}^{2}=.599$. The study found that ethical values significantly predicted organizational performance, $\beta=.774, \mathrm{t}(122)=13.452$, $\mathrm{p}=.000$. The study concluded/recommended that an organization culture grounded on ethics precipitates the delivery of core mandate of quality training, research, innovation and human capital development in universities.
\end{abstract}

Keywords: Ethics, higher education, global economy, leadership, attributes, precipitates, success, management.

\section{Introduction}

About one billion inhabitants is hosted in the Sub-Saharan African region with over two hundred public universities and a fast-growing number of private universities (Friescenhahn, 2014). A big percentage of scholars agree that higher education at the university level is most significant contributing factor for the region's fast development, transformation and future sustainability (Mouton, 2011; Sifuna \& Sawamura, 2010). The management of global resources adequately need a population with capacity 
to sustain them due to pressure from the ever-changing environment. This requires an inherent ethical value system to ensure survival of the next generation. The knowledge economy discourse characterizes the new relationship between higher education, the state and society, and the economy in this age of globalization. Institutions of higher education core functions consist of teaching, research and community extension service (UNESCO, 2010). The output by Higher Education institutions becomes increasingly important for international competition of a nation through generation, application, and dissemination of knowledge as heavily grounded in a strong ethical value system.

Evidence presented from past studies suggest that being ethical is a critical contributing factor in organizational success in Kenya in terms of credibility, dependability, and possessing best practices paradigm in the global higher education landscape. Webometric Ranking of Universities (2016) did not rate Kenyan universities as envisioned in the strategic plan, as a consequence there is need to address the gaps because the strategic leadership theory which underpins this study holds that organizations are images of the top leadership in those units. Gaps have been identified in policy adherence and enforcement areas, university boards have not lived to the expectations hence lack of best practices on human resource management and financial resource mobilization for a sustainable growth and survival and shortage of research in leadership role in universities. The question is whether this failure is due to lack of ethical values and practices? The role of higher education as a norm should focus on knowledge creation and transmission with an ethical orientation to the students to enhance economic and political transformation in Kenya. This study therefore examined organization management success as explained by ethical considerations with reference to private universities in Kenya.

\section{Literature Review \\ Theoretical Framework}

The theoretical orientation for this study is anchored on the strategic leadership theory which asserts that companies are reflections of their top managers, and that the specific knowledge, experience, values and preferences of top managers are reflected not only in their decisions, but in their assessments of decision environments (Ireland, Hitt \& Hoskisson, 2013). Morrill (2010) submits that theory gives rise to knowledge about leadership and to methods of decision making for leadership. Leadership is understood as the enactment of shared purposes which can frame the construction of an applied and integrative discipline for the exercise of strategic leadership.

The study is conceptualized on the basis of the Strategic Leadership theory with emphasizes on ethical values as a construct that underscores the 
interplay of the three variables that is ethical leadership, code of ethics and ethical rewarding.

\section{Ethics}

Ethics is referred to as employees' perceptions of their firm's authentic/virtuous practices (Jin \& Drozdenko, 2010). Employees' perceptions of corporate ethics tend to serve as ethical standards when they make decisions on ethics-related issues (Kish-Gephart, Harrison \& Treviño, 2010). Employee perceptions of corporate ethics are meaningful predictors of work outcomes, such as job satisfaction (Tsai \& Huang, 2008) and organizational commitment. Consensus regarding the dimensions or components comprising corporate ethics is lacking.

Ireland et al., (2013) submits that good governance practices are embedded and emphasized on organizational ethical practices. Globally, an organization is believed to have integrity in how it conducts its business based on the credibility, reliability, inimitability and best practices which are sustainable. This study examined the strategies employed by the universities to improve ethical values, regulations and policies regarding ethical codes for the workers, financial systems, procurement and recruitment, selection and separation.

Detert, Treviño and Sweitzer (2008), has classified ethical climates into 10 dimensions: ethical environment, employee focused, community focused, obedience to authority, code implementation, self-interest, efficiency, rules and procedure, personal ethics, and law and professional codes.

There are three dimensions of corporate ethics based on the core of firms' ethical behaviors or characteristics: external, internal and employee ethics. This conceptualization is consistent with the ethics qualities model proposed by Kaptein and Van Dalen (2000), that covers three domains of ethical practices: a firm's relationships with external stakeholders, its internal ethical functioning, and the morality and ethical behaviors of employees. These three dimensions are consistent with three distinct approaches to corporate ethics research that focus on the consequence, context and conduct aspects of ethics. The dimension's deal with inconsistencies among different typologies of ethical environment as well as to provide an overarching classification of corporate ethics. Ethical practices increase a firm's effectiveness to implement its strategies. This encourages and enables people at all organizational levels to act ethically when doing what is necessary to implement the firm's strategies. As a consequence, private universities must have strong ethical practices to be aligned to their strategic plans. This ensures that the organizational processes are handled with integrity, fairness, with a focus to providing good service delivery to the stakeholders. 
Chun, Shin, Choi and Kim (2013), suggests that the three dimensions of corporate ethics, internal ethics is most strongly related to employees' collective organizational commitment. When employees perceive that their organization adheres to legal and ethical standards, they become more committed to their organization. Endorsement of ethical principles reduces ambiguity about the roles and behaviors of employees, this offers employees a clear sense of what is expected and how they should behave within the organization. Furthermore, internal ethics fosters a justice climate within the firm, thereby causing employees to feel greater commitment to their workplace. However, the present findings should not be interpreted as evidence of inconsequential roles of the other two dimensions of corporate ethics that is, external and employee ethics (Gong, Chang \& Cheung, 2010). Although internal ethics is the strongest predictor of employees' commitment, external and employee ethics also have positive and significant relationships with collective commitment.

Jacinto and Carvalho (2009), in a study found out that employees heightened organizational commitment was positively related to both types of their organizational citizen behavior. Although this finding reflects those of previous studies of organizational citizen behavior. Note that the present study empirically demonstrates the commitment - organizational citizen behavior relationship at the firm level, which has been lacking in organizational citizen behavior literature dominated by the individual and group-level studies.

In practical terms, being ethical can be beneficial to firms, making it a worthwhile endeavor (Scott, 2008). Although it can involve multistep processes and its consequences might not be immediately noticed, firms with a high degree of internal ethics can achieve better financial performance through their employees' collective commitment and organizational citizenship behavior. It is apparent that employees' strong commitment to their organization and organizational citizenship behavior to bring a host of benefits to the workplace. Therefore, top managers should not overlook the importance of ethical management and be aware that being ethical can indeed pay off. Based on the finding that internal ethics is the strongest predictor of collective commitment, firms may best benefit from directing their ethical efforts toward promoting internal ethics.

Managers can attempt to facilitate their internal ethical functioning through diverse routes, such as establishing a code of ethics and guidelines in accordance with the legal and professional standards (Thomas, Schermerhorn, \& Dienhart, 2004). Furthermore, human resource practices (such as ethics training, incentivizing ethical behaviors) can be implemented to bolster internal ethics and enforce ethical operation. Schwartz, Dunfee, and Kline (2005), argue that simply meeting legal obligations might be insufficient because it does not allow firms to adapt to rapidly changing legal 
environments and to intensifying public scrutiny. These authors state that firms should reflect comprehensive ethical responsibility in their guidelines for decision making, particularly at the top echelon. To achieve this objective, a firm's board of directors can perform a critical role by establishing a code of ethics, thus shaping the ethical tone by demonstrating examples and actions.

\section{Organizational Success}

According to Richard et al., (2013), the actual outcomes and results of an organization as measured against its intended goals and objectives constitutes organizational performance. Organizational performance comprises three specific areas of the firm outcomes: financial performance such as profits, return on assets, return on investment; product market performance such as sales, market share, and shareholder return such as total shareholder return, economic value added. Armstrong (2017), defines performance as the record of outcomes produced on a specified job function or activity during a specified period. Therefore, performance is measured in terms of output and outcome, profit, internal processes and procedures, organizational structures, employee attitudes, and organizational responsiveness to the environment among others (William 2002). In recent years, many organizations have attempted to manage organizational performance using the balanced scorecard methodology (Kaplan \& Norton, 2001) where performance is tracked and measured in multiple dimensions such as: financial performance (e.g. shareholder return), customer service, social responsibility (e.g. corporate citizenship, community outreach) and employee stewardship. Balanced scorecard also identifies the measures used to monitor, review and assess performance (Armstrong, 2017).

The success of any organization is contingent on the capability of its top managers, leaders and a sustainable organizational culture created by those leaders. The belief and value systems created by the leaders always influence its performance (Soebbing et al. 2015). According to Ssekakubo et al., (2015), leadership competencies have a direct positive effect and always improves employee performance. This is further affirmed by researchers who have focused on the relationship between the competencies of leaders and how their organizations perform in the world economies. Pradhan and Pradhan (2015) agrees that, leadership is a contemporary slogan because individuals in charge of organizations would rather prefer being called as leaders rather than as managers.

According to McNair et al., (2011) says on one hand, that the art of motivating teams or groups of a workforce to appropriately to achieve a common goal is leadership. The researchers further submit that, the abilities to persuade other people, on behalf of the organization, to perform tasks necessary to achieve the organization's objectives and to communicate its 
vision to others demonstrate leadership competencies. There is mechanism of creating followers through skills, abilities and knowledge. Overstreet et al. (2014) on the other hand, consider competent leaders to have innate qualities whereas others say that competent leaders are made. Subsequently, both schools of thought agree that; some leaders have inborn qualities, but these may not be enough to ensure organizational success. Whereas some leaders require skills development through training and more experience before those leaders can be considered competent.

Success includes the definite outcomes of an organization as measured against its intended goals and objectives. According to Richard, Devinney, Yip and Johnson (2009), organizational performance incorporates three areas of firm outcomes: financial performance (profits, return on assets and return on investment), product market performance (sales, market share) and shareholder return (total shareholder return, economic value added). Currently, many organizations strive to manage organizational performance using the balanced scorecard where performance is monitored and measured in multiple dimensions such as: financial performance (shareholder return), customer service, corporate social responsibility (corporate citizenship, community outreach) and employee stewardship (Kaplan \& Norton, 2001). The measurement of performance contracting outlines the expectations (the work, the results to be attained and the attributes) and competencies required to achieve results. Armstrong (2017), affirms that performance contracting identifies the measures used to monitor, review and assess performance indicators.

According to Pradhan and Pradhan (2015), competent leadership is built upon various variables and characteristics, such as values, knowledge, intellectual drive, ethics, charisma, creativity, self-confidence and courage over a period in the organization. For a leader to demonstrate competence, there must be a purpose and a balanced personality as well as skills that can be applied to put purpose in question. Asree et al., (2010), further contends that vision, integrity, openness, dedication, and creativity among leaders is recipe for all employees to succeed and this ensures that organizations improve its performance.

The capabilities and skills leaders should employ must contain mentoring and coaching, leading and motivating, problem solving and decision making, communicating and listening, and influencing and negotiating which form succession plans (Tomal \& Jones, 2015). A relationship between leadership competencies and cognitive competencies exists. Globalization is another compelling factor where performance of an organization is contingent upon the effectiveness and flexibility of its leaders (Soebbing et al. 2015). High performing leaders tend to act as agents of change 
by empowering employees and often ensure that organizations adapt and succeed while recognizing the satisfaction of customers.

The iceberg model according to Bello (2012), that hypothesizes that leadership competencies are categorized into two; dominant competence and hidden competence. The first category that is the dominant competence is concrete where leaders employ acquired skills to execute their duties. This category of competence ensures that employees are doing their best to enable the organization to meet its long and short-term objectives. The second category is hidden competence which involves the community skills and personal knowledge that serve as inherent advantages for organizational leaders.

According to Kaplan and Norton (2001), the Balanced Scorecard allows organizations to build a management system that manages strategy of the organization. Strategy means communicating in a way that everyone can understand the plan for success. This therefore means that focused navigation in the organization to align strategy, and organization means to mobilize all employees to act in different ways that will link together across the business. The Balanced Scorecard provides a framework to look at strategy from four different perspectives; Financial, Customer, Internal Business Processes, and Learning and Growth. It gives managers the accurate information to make important decisions that affect everyone in the company.

\section{Methodology}

The study adapted positivism as the research philosophy. Positivism as a research paradigm is premised on measurable observations that lead themselves to statistical analysis. The use of appropriate research philosophy and philosophies help researchers to eliminate unrelated factors from the research (Cooper \& Schindler, 2014). The study adopted a descriptive correlational research design which determines if the two variables are correlated. This therefore implies whether an increase or decrease in one variable corresponds to an increase or decrease in the other variable.

The target population for this study included all the 17-chartered private as per MoEST (2016) with unit of analysis in the board members, vice chancellors, academic deans and heads of departments (finance, quality assurance, research, security, human resource and co-curricular activities) as the unit of analysis. Purposive sampling was used to sample board members and the study adopted census by considering all the elements of the population given they were less than 200 (Israel, 2009). Both primary and secondary data were used where primary data was collected by use of structured questionnaires and observations and secondary data was drawn from literature review of studies done in the area. The main tool for data collection was questionnaires, then analyzed by use of descriptive statistics (percentages, 
means, and standard deviation) and inferential statistics (correlations and linear regression) which were used to determine whether there were significant association/linear relationships between the predictors and the outcome variable using SPSS. Prior to conducting inferential analysis assumptions for linear regression such as checking for normality of the data, homoscedasticity, multicollinearity and linearity were done.

\section{Results}

\section{Effect of Ethical Values on Organizational Success}

The study examined the effect of ethical values as a derterminant of organizational performance in private universities in Kenya. Data was analyzed at two levels where the first level entailed determining ethical values. The second part involved analyzing results on the effect of ethical values on organizational performance.

\section{Factor Analysis Results on Ethical Values}

Factor analysis was conducted in the study to describe variability among items of ethical values. Ethical values construct was measured using sixteen (16) items thereby the construct was factor analyzed to come up with an appropriate measure. The study found that ethical values had KMO value of 0.857 and Bartlett's test, $x 2(120, N=124)=1146.143, p=.000$. This was meritorious; that means the adequacy of the sample was acceptable. Therefore, sampling was adequate for ethical values as given by the Kaiser-Meyer-Olkin Measure of Sampling Adequacy value.

The study sought to determine the factor loadings for ethical values. The findings obtained indicated that "The university has ethical policy for reviewing salaries of the employees" had the highest factor loading in the first component with 0.871 while "The university has a selection and recruitment policy" had the highest factor loading of 0.610 in the second component. university has ethical policy for reviewing salaries of the employees, $26.7 \%$ neither agreed nor disagreed, 10.8\% strongly agreed and 22.5\% disagreed while $9.2 \%$ strongly disagreed. Some respondents $(33.3 \%)$ agreed that hard working employees are financially rewarded for their services, $28.3 \%$ neither agreed nor disagreed, $7.5 \%$ strongly agreed and $15.8 \%$ disagreed while $15 \%$ strongly disagreed.

Further, the findings indicated that some respondents $(30.6 \%)$ agreed that the university has a policy for giving bonuses to outstanding employees, $23.1 \%$ neither agreed nor disagreed, $11.6 \%$ strongly agreed and $18.2 \%$ disagreed while $16.5 \%$ strongly disagreed. Some respondents $(45.1 \%)$ agreed that new employees are oriented in to the university's values, and this greatly influences their performance and productivity, $18.9 \%$ neither agreed nor disagreed, $21.3 \%$ strongly agreed and $12.3 \%$ disagreed while $2.5 \%$ strongly 
disagreed. Some respondents $(27.5 \%)$ agreed that there is a clear measurement of the economic and people impact of ethical behaviors, 23.3\% neither agreed nor disagreed, $11.7 \%$ strongly agreed and 25.8\% disagreed while $11.7 \%$ strongly disagreed. Finally, some respondents $(31.4 \%)$ agreed that the university has saved on finances and time due to its ethical standards of procurement, $32.2 \%$ neither agreed nor disagreed, $14.9 \%$ strongly agreed and $13.2 \%$ disagreed while $8.3 \%$ strongly disagreed.

\section{Mean and Standard Deviation for Ethical Values}

The study also sought to analyze the views of respondents on Ethical Values using a table of means and standard deviation. A Likert scale data was collected rating the views in a scale. The mean results are therefore given on a scale interval where a mean value of 1 is an indication of strongly disagree; 2 is disagree; 3 is neutral, 4 is agree and a mean value of 5 is an indication of strongly agree. According to the findings, the respondents agreed to the following statements: The university has policies and regulations regarding the standard acceptable behavior $(M=4.19, S D=0.819)$; the university has policies and regulations regarding the standard acceptable behavior $(M=4.06$, $S D=0.891)$; The University has systems to ensure high performance and ethical behaviors $(M=3.92, S D=0.936)$; ethics training motivates employees in the work place $(M=3.63, S D=0.972)$; new employees are oriented in to the university's values, and this greatly influences their performance and productivity $(M=3.70, S D=1.018)$ employees role in the firm determines his/her training needs $(M=3.76, S D=0.882)$; the university has a selection and recruitment policy $(M=4.13, S D=0.944)$ and the university considers qualifications and experience when hiring employees $(M=4.14, S D=0.912)$.

The findings also indicated (see table 1) that the respondents neither agreed nor disagreed to the following statements: the university provides ethical training to newly hired staff to prepare them for their new positions ( $M$ $=3.41, S D=1.238)$; the university offers short training on ethics in form of seminars $(M=3.29, S D=1.221)$; the university offers short training on ethics in form of seminars $(M=3.29, S D=1.221)$; staff members are periodically given opportunity in form of workshops to discuss the ethical issues they are experiencing $(M=3.11, S D=1.268)$; the university has ethical policy for reviewing salaries of the employees $(M=3.12, S D=1.154)$; hard working employees are financially rewarded for their services $(M=3.02, S D=1.184)$; the university has a policy for giving bonuses to outstanding employees $(M=$ $3.02, S D=1.274)$; there is a clear measurement of the economic and people impact of ethical behaviors $(M=3.02, S D=1.216)$; the university has saved on finances and time due to its ethical standards of procurement $(M=3.31, S D$ $=1.133$ ). 
Table 1: Means and Standard Deviations for Ethical Values

\begin{tabular}{|l|l|l|l|}
\hline & $\mathrm{N}$ & Mean & $\begin{array}{l}\text { Std. } \\
\text { Deviation }\end{array}$ \\
\hline $\begin{array}{l}\text { The university has systems to ensure high } \\
\text { performance and ethical behaviors }\end{array}$ & 121 & 3.9174 & .93619 \\
\hline $\begin{array}{l}\text { The university has policies and regulations } \\
\text { regarding the standard acceptable behavior }\end{array}$ & 122 & 4.1967 & .81959 \\
\hline $\begin{array}{l}\text { The HRM Department has a written policy on } \\
\text { advertising for employment vacancies }\end{array}$ & 122 & 4.0574 & .89350 \\
\hline $\begin{array}{l}\text { The university has a selection and recruitment } \\
\text { policy }\end{array}$ & 122 & 4.1311 & .94432 \\
\hline $\begin{array}{l}\text { The university considers qualifications and } \\
\text { experience when hiring employees }\end{array}$ & 122 & 4.1393 & .91196 \\
\hline $\begin{array}{l}\text { The university provides ethical training to newly } \\
\text { hired staff to prepare them for their new positions }\end{array}$ & 122 & 3.4098 & 1.23819 \\
\hline $\begin{array}{l}\text { The university offers short training on ethics in } \\
\text { form of seminars }\end{array}$ & 121 & 3.2893 & 1.22092 \\
\hline $\begin{array}{l}\text { Ethics training motivates employees in the work } \\
\text { place }\end{array}$ & 122 & 3.6311 & .97235 \\
\hline $\begin{array}{l}\text { Employees role in the firm determines his/her } \\
\text { training needs }\end{array}$ & 122 & 3.7623 & .88190 \\
\hline $\begin{array}{l}\text { Staff members are periodically given opportunity } \\
\text { in form of workshops to discuss the ethical issues } \\
\text { they are experiencing }\end{array}$ & 122 & 3.1148 & 1.26750 \\
\hline $\begin{array}{l}\text { The university has ethical policy for reviewing } \\
\text { salaries of the employees }\end{array}$ & 120 & 3.1167 & 1.15361 \\
\hline $\begin{array}{l}\text { Hard working employees are financially rewarded } \\
\text { for their services }\end{array}$ & 120 & 3.0250 & 1.18437 \\
\hline $\begin{array}{l}\text { The university has a policy for giving bonuses to } \\
\text { outstanding employees }\end{array}$ & 121 & 3.0248 & 1.27451 \\
\hline $\begin{array}{l}\text { New employees are oriented in to the university’s } \\
\text { values, and this greatly influences their } \\
\text { performance and productivity }\end{array}$ & 122 & 3.7049 & 1.01793 \\
\hline $\begin{array}{l}\text { There is a clear measurement of the economic and } \\
\text { people impact of ethical behaviors }\end{array}$ & 120 & 3.0167 & 1.21602 \\
\hline $\begin{array}{l}\text { The university has saved on finances and time due } \\
\text { to its ethical standards of procurement }\end{array}$ & 121 & 3.3140 & 1.13309 \\
\hline
\end{tabular}

The study sought to determine the relationship between ethical values index and organizational performance using correlation analysis and found 
that the two variables were strongly correlated $r(123)=.774, p=.000$. The results are as shown in Table 2.

Table 2: Correlation Analysis on Ethical Values Index

\begin{tabular}{|l|l|l|}
\hline \multicolumn{2}{|l|}{} & $\begin{array}{l}\text { Organizational } \\
\text { Performance }\end{array}$ \\
\hline \multirow{3}{*}{ Ethical Values } & Pearson Correlation & $.774^{* *}$ \\
\cline { 2 - 3 } & Sig. (2-tailed) & .000 \\
\cline { 2 - 3 } & $\mathrm{N}$ & 123 \\
\hline
\end{tabular}

**. Correlation is significant at the 0.01 level (2-tailed).

Table 3: Model Summary for Ethical Values

\begin{tabular}{|l|l|l|l|l|}
\hline Model & $\mathrm{R}$ & R Square & $\begin{array}{l}\text { Adjusted } \\
\text { Square }\end{array}$ & $\begin{array}{l}\text { Std. Error of the } \\
\text { Estimate }\end{array}$ \\
\hline 1 & $.774^{\mathrm{a}}$ & .599 & .596 & .46911 \\
\hline
\end{tabular}

Predictors: (Constant), Ethical Values

The findings indicated that the significance value in testing the reliability of the model for the relationship between ethical values and organizational performance was $F(1,121)=180.965, p=0.00$. Therefore, the model is statistically significant in predicting the relationship between ethical values and organizational performance. Results are as presented in Table 4.

Table 4: ANOVA for Ethical Values

\begin{tabular}{|l|l|l|l|l|l|l|}
\hline \multicolumn{2}{|l}{ Model } & $\begin{array}{l}\text { Sum of } \\
\text { Squares }\end{array}$ & df & $\begin{array}{l}\text { Mean } \\
\text { Square }\end{array}$ & F & Sig. \\
\hline \multirow{3}{*}{1} & Regression & 39.823 & 1 & 39.823 & 180.965 & $.000^{\mathrm{b}}$ \\
\cline { 2 - 8 } & Residual & 26.627 & 121 & .220 & & \\
\cline { 2 - 6 } & Total & 66.450 & 122 & & & \\
\hline
\end{tabular}

Dependent Variable: Organizational Performance

Predictors: (Constant), Ethical Values

The study found that ethical values significantly predicted organizational performance, $\beta=.774, t(122)=13.452, p=.000$. This finding implied rejection of the null hypothesis since the $\mathrm{p}$ value was less than $<.05$ set by the study. The study therefore concluded that ethical values significantly influence organizational performance in private universities in Kenya. The results are presented in Table 5. 
Table 5: Regression Coefficients for Ethical Values

\begin{tabular}{|c|c|c|c|c|c|c|}
\hline \multirow{2}{*}{\multicolumn{2}{|c|}{ Model }} & \multicolumn{2}{|c|}{$\begin{array}{l}\text { Unstandardized } \\
\text { Coefficients }\end{array}$} & $\begin{array}{l}\text { Standardized } \\
\text { Coefficients }\end{array}$ & \multirow[t]{2}{*}{$\mathrm{t}$} & \multirow[t]{2}{*}{ Sig. } \\
\hline & & B & Std. Error & Beta & & \\
\hline \multirow[b]{2}{*}{1} & (Constant) & 1.038 & .212 & & 4.891 & .000 \\
\hline & $\begin{array}{l}\text { Ethical } \\
\text { Values }\end{array}$ & .786 & .058 & .774 & 13.452 & .000 \\
\hline
\end{tabular}

a. Dependent Variable: Organizational Performance

The findings obtained in the study implied that for every one-unit change in ethical values, organizational performance increases by 0.774 hence implying a positive impact of ethical values on organizational performance.

\section{Conclusion}

The study determined that staff members were not periodically given opportunity in form of workshops to discuss the ethical issues they are experiencing, the universities did not have enough ethical policies for reviewing salaries of the employees, hardworking employees were not financially rewarded for their services and the universities had fewer policies for giving bonuses to outstanding employees. That employees responded positively to corporate ethics in terms of their organizational attitudes and workplace behaviors, ultimately enhancing institutions financial performance. In addition, the study determined that it was apparent that employees' strong commitment to their organization and organizational citizenship behavior to bring a host of benefits to the workplace.

The study therefore recommends that private universities in Kenya can increase their admission quarters when they embrace a strong ethical culture such that industry can recon with the standards. This can reduce the negative perception of corruption as reported in the global corruption index. This can attract partnerships with industry and academia to improve economic development in the country and can be replicated globally.

\section{References}

1. Armstrong, M. (2017). Armstrong's Handbook of Performance Management: An Evidence-Based Guide to Delivering High Performance, London. 6th. Kogan PAGE.

2. Asree, S., Zain, M., \& Rizal Razalli, M. (2010). "Influence of leadership competency and organizational culture on responsiveness and performance of firms", International Journal of Contemporary Hospitality Management, Vol. 22 No. 4, pp. 500-516. 
3. Bello, S.M. (2012). "Impact of ethical leadership on employee job performance”, International Journal of Business and Social Science, Vol. 3 No. 11, pp. 228-236.

4. Choi, J. H., \& Lee, K. P. (2013). Effects of employees' perceptions on the relationship between HR practices and firm performance for Korean firms. Personnel Review, 42(5), 573-594.

5. Chun, J. S., Shin, Y., Choi, J. N., \& Kim, S. M. (2013). How Does Corporate Ethics Contribute to Firm Financial Performance? The Mediating Role of Collective Organizational Commitment and Organizational Citizenship Behavior Journal of Management Vol. 39 No. 4.

6. Cooper, D., \& Schindlers, P. (2014). Business Research Methods 12th Ed. New York MCGRAW HILL Irwin.

7. Creswell, J. W. (2010). Understanding Research: A Consumer's Guide (1st Ed). Merrill Education, CA: SAGE.

8. Creswell, J. W. (2014). Designing and Conducting Mixed Methods Research (4ndEd) Thousand Oaks, CA: SAGE.

9. Creswell, J. W., \& Plano Clark, V. L. (2011). Designing and conducting mixed methods research (2nd ed.). London: SAGE Publication.

10. Detert, J. R., Treviño, L. K., \& Sweitzer, V. L. (2008). Moral disengagement in ethical decision making: A study of antecedents and outcomes. Journal of Applied Psychology, 93: 374-391.

11. Friescenhahn, I. (2014). Marking Higher Education Work for Africa. Facts and Figures.

12. Gong, Y., Chang, S., \& Cheung, S. (2010). High performance work system and collective OCB: A collective social exchange perspective.

Human Resource Management Journal, 20: 119-137

13. Ireland, R. D., Hoskisson, R.E., \& Hitt, M. A. (2013). The Management of Strategy Concepts and Cases, $10^{\text {th }}$ ed. Mason, OH: South-Western CENGAGE Learning.

14. Israel, G. D. (2009). Determining Sample Size. Program Evaluation and Organizational Development, Institute of Food and Agricultural Sciences (IFAS), University of Florida, Gainesville.

15. Jacinto \& Carvalho, (2009). Corporate Social responsibility, employees' performance and identification

16. Jin, K. G., \& Drozdenko, R. G. (2010). Relationships among perceived organizational core values, corporate social responsibility, ethics, and organizational performance outcomes: An empirical study of information technology professionals. Journal of Business Ethics, 92: 341-359. 
17. Kaplan, R. S., \& Norton, D.P. (1992), "The balanced scorecard measures that drive performance", Harvard Business Review, JanuaryFebruary, pp. 71-9.

18. Kaplan R. S., \& Norton, D.P. (2001). The strategy focused organization, Strategy \& Leadership, 29(3): 41-42; R.S. Kaplan \& D.P Norton, 2000, The Strategy-Focused Organization: How Balanced Scorecard Companies Thrive in the New Business School Press.

19. Kaptein, M., \& Van Dalen, J. (2000). The empirical assessment of corporate ethics: A case study. Journal of Business Ethics, 24: 95-114.

20. Kish-Gephart, J. J., Harrison, D. A. \& Treviño, L. K. (2010). Bad apples, bad cases, and bad barrels: Meta-analytic evidence about sources of unethical decisions at work. Journal of Applied Psychology, 95: 1-31.

21. Mcnair, D. E., Duree, C.A. \& Ebbers, L. (2011). "If I knew then what I know now: using the leadership competencies developed by the American association of community colleges to prepare community college presidents", Community College Review, Vol. 39 No. 1, pp. 325.

22. Ministry of Education Science and Technology Report, (2016).

23. Morrill, R. L. (2010). Strategic Leadership, Integrating Strategy and Leadership in Colleges and Universities, NY. Rowman Littlefield Publishers INC.

24. Mouton, J. (2011). The State of Doctoral Training in SSA: Statistics Analysis and Challenges.

25. AAU Conference of Rectors, Vice Chancellors and Presidents. Stellenbosch.

26. Overstreet, R. E. Hazen, B.T., Skipper, J. B., \& Hanna, J. B. (2014). "Bridging the gap between strategy and performance: using leadership style to enable structural elements", Journal of Business Logistics, Vol. 35 No. 2, pp. 136-149.

27. Pradhan, S., \& Pradhan, R. K. (2015). "An empirical investigation of relationship among transformational leadership, affective organizational commitment and contextual performance", Vision: The Journal of Business Perspective, Vol. 19 No. 3, pp. 227-235.

28. Richard, P. J., Devinney, T. M., Yip, G.S. \& Johnson, G. (2009). Measuring Organizational Performance: Towards Methodological Best Practice. Journal of Management.

29. Richard, A. (2013). Theory Building in Applied Disciplines. San Francisco, CA: Berrett-Koehler Publishers.

30. Sifuna, D.N and Sawamura, N. (2010). Challenges of Quality Education in Sub-Saharan African Countries Nova Science Publishers. 
31. Scott, W. R. (2008). Institutions and Organizations: Ideas and Interests, 3rd ed. SAGE Publications, Los Angeles, CA.

32. Soebbing, B. P., Wicker, P., \& Weimar, D. (2015). "The impact of leadership changes on expectations of organizational performance", Journal of Sport Management, Vol. 29 No. 5, pp. 485-497.

33. Ssekakubo, J., Lwanga, F., \& Ndiwalana, G. (2015). "Employee motivation, job satisfaction and organizational performance in Uganda's oil sub-sector", Global Advanced Research Journal of Management and Business Studies, Vol. 3 No. 7, pp. 315-324.

34. Schwartz, M. S., Dunfee, T. W., \& Kline M. J. (2005). Tone at the Top: An Ethics Code for Directors? Journal of Business Ethics 58 (1-3):79.

35. Tomal, D. R., \& Jones, K. J. (2015). "A comparison of core competencies of women and men leaders in the manufacturing industry", The Coastal Business Journal, 14 (1), 13-25.

36. Thomas, Schermerhorn, \& Dienhart, (2004) Strategic leadership of ethical behavior in business

37. Academy of Management Perspectives Vol. 18, No. 2

38. Tsai, M. T., \& Huang, C. C. (2008). The relationship among ethical climate types, facets of job satisfaction, and the three components of organizational commitment: A study of nurses in Taiwan. Journal of Business Ethics, 80:565-581.

39. UNESCO (2010). Education for Sustainable Development - UN decade 2005 - 2014, www.unesco/org/education/desd. UNESCO (2005) EFA Global Monitoring Report (Online) http://www/portal.unesco.org/education/en/ev.php.url (April 27, 2005).

40. Yukl, G. A. (2013). Leadership in Organizations, 8th Edition. State University of New York, Albany.

41. Zahra, S., Hayton, J., \& Salvato, C. (2004). "Entrepreneurship in family vs non-family firms: a resource-based analysis of the effect of organizational culture", Entrepreneurship Theory \& Practice, Vol. 28 No. 4, pp. 363-381. 